\title{
THE ALEDJO QUARTZITIC RUINS IN NORTHERN TOGO: GENESIS AND STRUCTURAL GEOMORPHOLOGY
}

\author{
MAHAMAN SANI TAIROU, PASCAL AFFATON, BAWOUBADI EDĖM SABI, N'KOUÉ \\ SIMPARA, FLORENT BOUDZOUMOU AND PAULINE YAWOA D. DA COSTA
}

\begin{abstract}
In northern Togo, the Aledjo Mountains represent a NE-SW to ENE-WSW trending segment of the Pan-African Dahomeyide orogen. This mainly quartzitic topography belongs to the external zone of the belt and, more precisely, to the eastern assemblage of the Atacora Structural Unit. It corresponds to a ruiniform landscape which resulted from an erosive sculpturing that started at the end of the Pan-African tectogenesis within the Dahomeyide Belt, at about 550 Ma. A first interpretation of these spectacular sculptures attributed their great variety to predisposition factors related to the petrographic heterogeneity of the quartzites and to the Pan-African tectogenesis. With reference to these genetic factors, the Aledjo quartzitic ruins are subdivided into two morphostructural groups related either to a combination of folding and erosion or fracturing and erosion. Moreover, the Aledjo ruiniform landscape may be considered as an attractive touristic target which can contribute to regional economic development in northern Togo.
\end{abstract}

KEY WORDS: Quartzitic Ruins, Aledjo Montains, Dahomeyide, Northern Togo, Morphogenesis

\section{INTRODUCTION}

The quartzites of the Aledjo Mountains display spectacular ruiniform landscapes made up of numerous and varied natural sculptures. These curious or mysterious sculptures are little or not at all known, apart from the famous "Aledjo Fault" which is exposed along a major international road. The present paper synthesizes a morphogenetic study of these ruiniform landscapes. Based on field observations and aerial photograph analysis, the main objectives of this paper are to identify the combination of genetic factors and to attempt a morphostructural classification of these ruins.

\section{1 - Geographic Framework}

The Aledjo Mountains stretch between longitudes $1^{\circ}$ and $1^{\circ} 25^{\prime} \mathrm{E}$ and latitudes $9^{\circ} 10^{\prime}$ and $9^{\circ} 20^{\prime} \mathrm{N}$. They display a picturesque NE-SW to ENE-WSW trending landscape in northern Togo (Fig. 1a). As in the entire North of Togo, the area studied is located in a Sudano-Guinean climate zone, with two contrasting seasons characterized by an average annual rainfall of 1000 to $1500 \mathrm{~mm}$. Nevertheless, the Aledjo-Kadara area, whose relief is more than $850 \mathrm{~m}$, has a distinctive climate marked by a relatively high humidity and an annual rainfall sometimes higher than $1500 \mathrm{~mm}$. The temperature in the Aledjo Mountains is very variable (20$35^{\circ} \mathrm{C}$ ) during the year. Hydrographically, these mountains correspond to a part of the watershed between the huge Mono and Oti basins. They thus represent the "water tower" feeding a dense network of small rivers with sustained low water flow. In the Aledjo Mountains, vegetation is a wood savannah and small dry forests rich in plant species (Woegan, 2007). The Aledjo Mountains and their surroundings are inhabited by the Tem people who are mainly agriculturalists.

Mahaman Sani Tairou, Département de Géologie, Faculté des Sciences, Université de Lomé, BP 1515 Lomé, Togo

Pascal affaton, Aix-Marseille Université, CNRS, IRD, CEREGE UMR34, BP 80, 13545 Aix-En-Provence cedex 04, France

Bawoubadi Edèm Sabi, Département de Géologie, Faculté des Sciences, Université de Lomé, BP 1515 Lomé, Togo

N'koué Simpara, Département de Géologie, Faculté des Sciences, Université de Lomé, BP 1515 Lomé, Togo

Florent Boudzoumou, Faculté des Sciences, Université Marien Ngouabi, B.P. 69 Brazzaville, Congo

Pauline Yawoa D. Da Costa, Département de Géologie, Faculté des Sciences, Université de Lomé, BP 1515 Lomé, Togo 


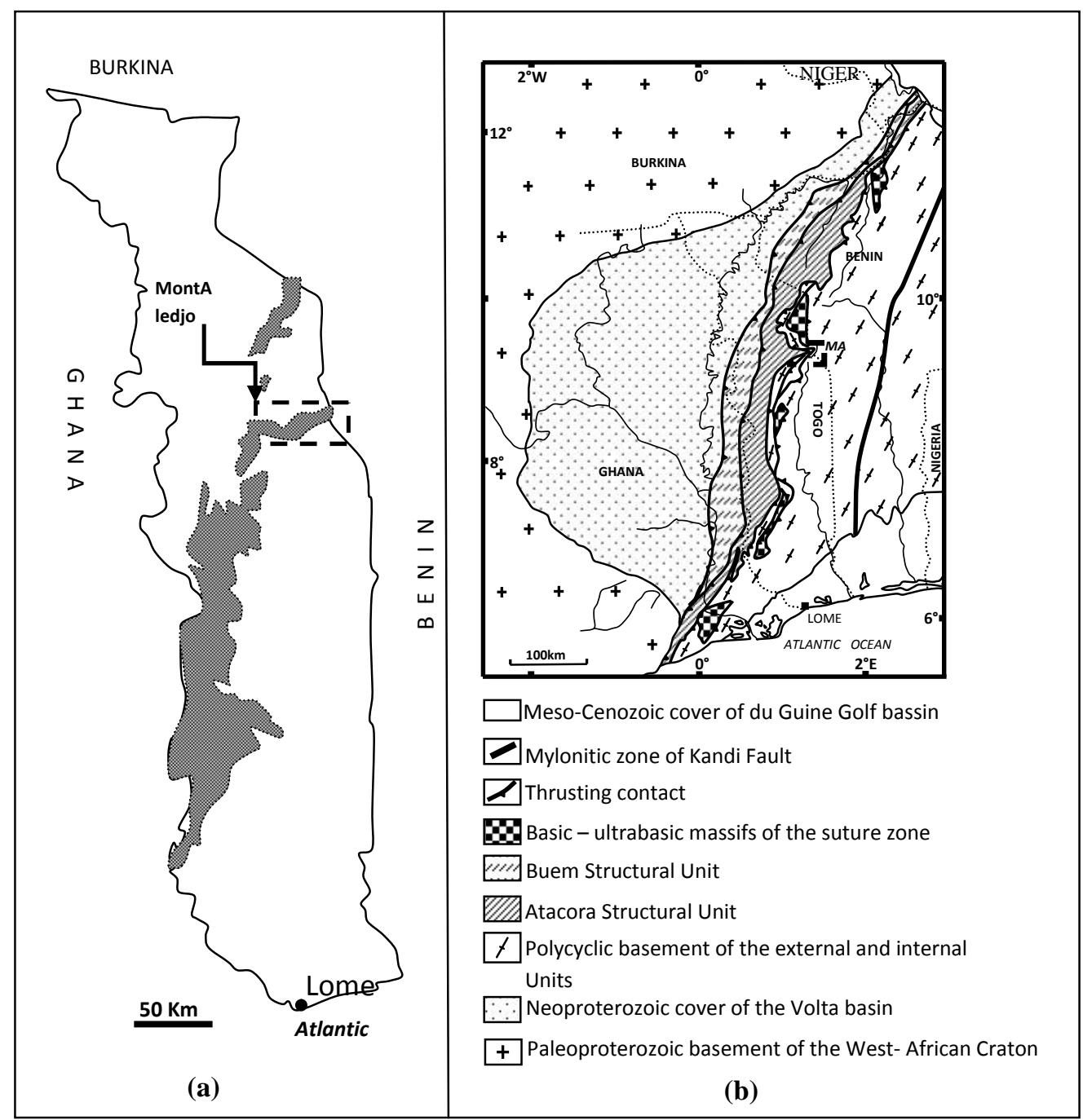

Figure 1 : Geographic location and geological setting of the Aledjo Mountains: a- zone of the principal reliefs (altitude $>600 \mathrm{~m}$ ) of the framework of the Dahomeyide Belt in Togo ("Mount Togo"); b- frontal units of the Dahomeyide orogen thrust on the Volta Basin which rests unconformably on the south-eastern margin of the West-African Craton.

\section{2 - Geological Setting}

The rock assemblage in the Aledjo Mountains (Fig. 1b) belongs to the Pan-African Dahomeyide Belt (Affaton, 1990). Considered as a collision belt, the Dahomeyide orogen is defined as a pile of overthrusting units or nappes composing its external, internal and suture zones (Trompette, 1979; Affaton et al., 1991; Tairou, 2006). The suture zone is expressed as a submeridian chain made up of the granulitic massifs of the Derouvarou (North Benin), Kabye-Kpaza, DjabatoreAnié and Ahito-Agou (Togo) and Akuse or Shai (SE Ghana) regions. The external zone is located to the West of the suture zone chain. It is mainly composed of (1) meta-sediments (various facies of quartzites, quartzand micaschists) in the Buem and Atacora Structural Units, (2) various orthogneisses constituting the polycyclic Kara-Niamtougou Unit, the Mo and plutonometamorphic Amlame-Kpalime nappe Complex (CaenVachette et al., 1979; Agbossoumondé et al., 2007; Tairou et al., 2009), and (3) kyanite-bearing quartzites and associated mica- and garnet-schists in the SokodeKemeni Unit (Tairou 2006). The internal zone, located to the East of the suture zone and covering the BeninoNigerian peneplain (Caby, 1989; Affaton, 1990; Affaton et al., 1991), comprises several gneisso-migmatitic units with granitoid intrusions. The Buem, or the outermost structural unit of the Dahomeyide Belt, overthrusts the Neoproterozoic-Palaeozoic cover in the Volta Basin (Fig. 1b). It is overthrusted by the Atacora Structural Unit which is mainly composed of a schistose western subunit ("Schistes de Kante") and a dominantly quartzitic eastern sub-unit considered as the framework of the Dahomeyide orogen and called "Monts Togo" (Simpara et al., 1985; Affaton, 1990; Tairou, 2006). The Aledjo Mountains form part of the quartzitic Atacora sub-unit (Noel et al., 1984; Sylvain et al., 1986; Tairou, 1995). It is an anticlinorial megastructure overtrusted, in the North, by the orthogneissic Kara-Niamtougou nappes and, in the South-East, by the meta-volcanosedimentary assemblage of the Sokode-Kemeni Unit (Tairou, 1995, 
2006). This megastructure, with a transverse orientation relative to the submeridian appearance of the Dahomeyide Belt, dips eastwards, under the internal gneissic nappes of the Benino-Nigerian peneplain. It is composed of varied quartzites, quartz-micaschists, garnet-micaschist and itabirite type ferriferous quartzites. These rocks are strongly imbricated because of the four folding phases that structured the Dahomeyide Belt (Simpara, 1978; Affaton, 1990; Affaton et al., 1991; Tairou, 2006; Tairou, et al., 2007).

\section{3 - Main Petrostructural Characteristics of the Aledjo Quartzites}

Aerial photographs of the Aledjo Mountains display a peculiar photofacies with clear NE-SW trending foliation traces cut by numerous high density fractures. This important fracture network gives rise to the photofacies the typical jagged appearance which characterizes ruiniform landscapes. Such landscapes appear as associations of slices of quartzite beds and bushes.

In outcrop, the Aledjo quartzites are multicoloured (whitish, reddish, brownish, yellowish, grayish or greenish grey) because of lichen coverings. They display numerous petrographic variants due to a relative abundance of mica and rock architecture. They include pure quartzites, coarse-grained and sometimes metaconglomeratic quartzites, very fine-grained quartzites and quartz-schists containing bands of micaschists. These quartzites generally contain muscovite and/or phengite, feldspars, tourmaline, chloritoid, biotite, garnet, chlorite and fuschsite (Tairou, 1995, 2006). The quartzites may be massive or foliated with platy parting. The parting plane of all the quartzite variants corresponds to the $S_{1}$ foliation, subparallel to the stratification $S_{0}$. Their peculiar tectonic style leads to discovering four superimposed Pan-African deformation phases (Tairou, 1995, 2006; Tairou, et al., 2007). The first phase corresponds to isoclinal P1 folds whose axial planes are refolded by the second generation folding (Fig. 2a). This second deformation phase is the most visible, with numerous centimetric to metric, heterotypical folds, with NE-SW trending subhorizontal axes (Fig. 2b). The third deformation phase is expressed as hectometric to kilometric $\mathrm{P}_{3}$ synforms and antiforms, with NE-SW trending axes. The fourth deformation phase led to kilometric folds such as the Aledjo Mountains megastructure. This megastructure, with a N70-12NE trending axis, defines the Atacorian virgation of Aledjo (Tairou, 2006). Finally, the Aledjo Mountain quartzites bear, at all scales, the imprints of intense fracturing associated particularly with the third and fourth deformation phases (Tairou et al., 2007).

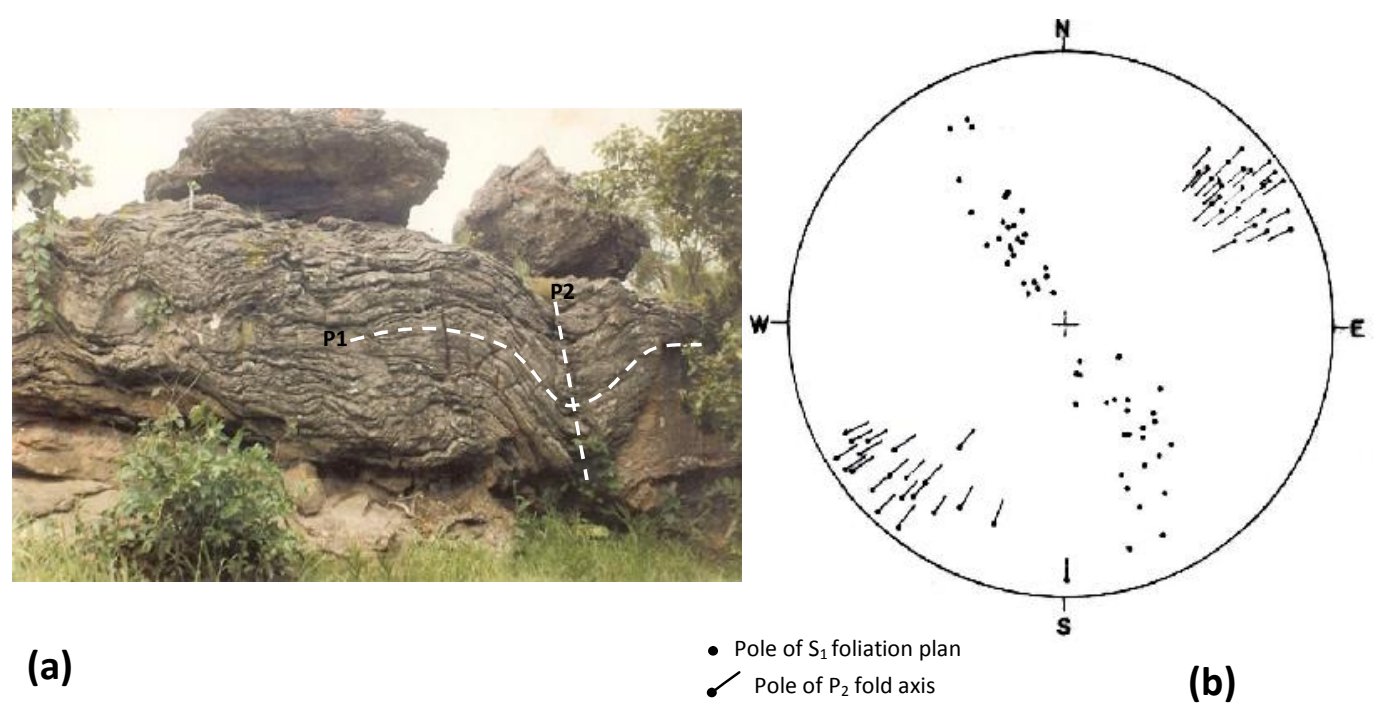

Figure 2: Characteristics of folding in the Aledjo Mountains quartzites. (a) $P_{1}$ axial plane refolded by $P_{2}$ folding; (b) Stereogram (upper hemisphere projection) summarizing the recorded $\mathrm{S}_{1}$ foliation planes and $\mathrm{P}_{2}$ fold axes at Kpewa.

\section{4 - Factors in the Genesis of the Quartzitic Ruins}

Ruiniform exokarsts generally result from carbonated rocks which have undergone various erosional and dissolutional processes. Nevertheless, heterogeneous rock assemblages also provide a favourable environment for the development of such a landscape littered with ruins, following a phenomenon of differential abrasion. But, in northern Togo, the spectacular and varied nature of the Aledjo sculptures probably originated from a combination of internal and external geodynamic factors affecting the quartzites. These factors are: (1) petrographic heterogeneity, (2) PanAfrican folding and metamorphism, (3) late Pan-African fracturing, and (4) post-Pan-African erosion.

\section{1 - Petrograghic Heterogeneity}

This is expressed by the great variety of the observed facies: pure quartzites, very fine-grained and coarsegrained, sometimes meta-conglomeratic quartzites, and quartz-schists with micaschist bands. This heterogeneity is a sedimentary inheritance which is observed in detailed stratigraphic columns of Neoproterozoic sandy 
sequences in the Volta Basin, with intercalations of clayey or clayey-silty horizons and sometimes microconglomeratic lenses (Drouet et al., 1984; Drouet, 1986; Affaton, 1990; Carney et al., 2010). In fact, the Aledjo Mountains quartzites are considered as lateral and tectono-metamorphic equivalents of the lower sequences of the Volta Basin (Affaton, 1975, 1990; Simpara, 1978; Affaton et al., 1980, 1991).

The variety of observed facies and the massive or platy architecture of the quartzitic beds favour differential erosion. The primary inheritance is thus an important factor of predisposition in the development of ruiniform landscapes.

\section{4-2- Pan-African Folding and Metamorphism}

The tectogenesis recorded by the Aledjo Mountains quartzites corresponds to the Pan-African event (600 \pm $150 \mathrm{Ma}$ ) that involved the eastern margin of the Volta Basin during the Dahomeyide Belt edification (Affaton 1990; Affaton et al., 1991). This major event led to the metamorphic transformation of sandy sequences into micaceous quartzites, followed by folding. The acquisition of an $S_{1}$ foliation (subparallel to the stratification $S_{0}$ ) and the folding of this foliation contributed to the imparting of a peculiar imprint on the topographic features due to erosion that became very active after the uplift of the orogen. The shapes of the complex sculptures underline the important role of both $\mathrm{P}_{1}$ and $\mathrm{P}_{2}$ foldings (Fig. 2).

\section{3 - Late Pan-African Fracturing}

The competent nature of the Aledjo quartzites has enabled the rocks to record a polyphase brittle deformation expressing the D3 and D4 late Pan-African phases of Tairou et al. (2007). On a regional scale, this fracturing is expressed by high cliffs or topographic scarps. In outcrop, these are represented by decimetric to metric fractures that cut the quartzites in many directions. These are subvertical and longitudinal NESW (N50 to N70) trending, transverse ENE-WSW to SENW (N120 to N160) trending, and N-S or E-W trending planes (Fig. 3a and b). The transverse fractures are dominant and represent dextral or sinistral strike-slip faults, with decametric to hectometric throws (Fig. 3c). These strike-slip faults are responsible for the jagged appearance of the ruiniform landscapes seen on aerial photographs. All the fracture planes subsequently became zones of weakness allowing linear streaming that is responsible of the alignment of the sculptures.

\section{4 - Post Pan-African Erosion}

The ruiniform landscapes of the Aledjo Mountains are the result of intense erosion that started after the uplift of the Dahomeyide orogen (550 Ma; Kalsbeek et al., 2012). The major agent of this long period of differential stripping is meteoric water. By rapid gullying of the less resistant of most micaceous quartzites, erosion resulted in numerous residual sculptures composed mainly of the harder quartzitic rocks. This disaggregation is also favoured by biological agents, mainly higher plants such as fig trees. The latter, developing their root system in slightly open fractures or in foliation planes, contributed to the rupturing of large rock masses. By gravity transport or gliding, blocks of separated rock crumble or collapse sometimes forming landslides. These landslides are responsible for the chaotic configuration overlain by metric blocks of quartzites. 

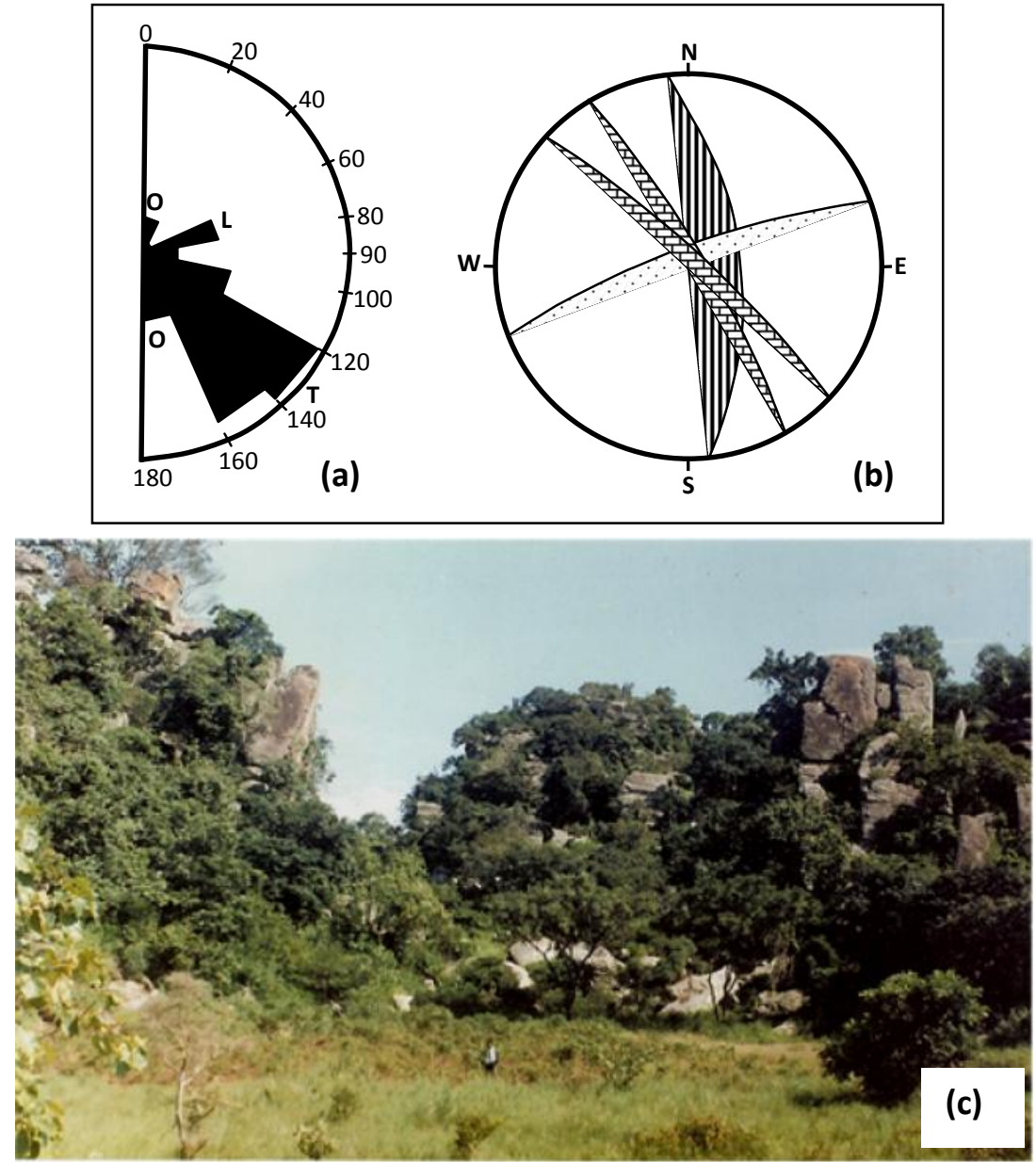

Fig 3: Some aspects of fracturing in Aledjo quartzites. (a) rose diagram of the distribution of fracture planes $(O=$ oblique, $L=$ longitudinal and $T=$ transverse); (b) cyclographic traces of median planes of the different fracture families; (c) example of hectometric strike-slip faults responsible for photofacies of the Aledjo Mountains.

\section{5 - Classification}

Considering the different morphostructural aspects of the Aledjo quartzitic ruins, one can distinguish shapes that favour the twin causal factors of fracturing/erosion or folding/erosion.

\section{1- Shapes Related to Fracturing/Erosion Factors}

They are the most numerous and are assembled in many ways of which the most frequent are piles of rocks, "walls", "raised bars" and "towers". Decametric to hectometric piles of rocks are delimited by two main transverse and subparallel fractures (Fig. 4a). Rock stacks several meters high result from the slicing of quartzite beds by numerous longitudinal fractures and joints. After erosion, large blocks are re-equilibrated in the pile by minor gravitational movements. The removal of some blocks during landslides results in spectacular relics such as those called "the devil's vehicle" (Fig. 4b).
The "walls" are continuous rock slices of decimetric to metric thickness demarcated by subparallel transverse fractures. They appear as big eroded walls separated by wide corridors (Fig. 4c). The "raised bars" are relics in the form of vertical columns of decimetric to metric thickness composed of competent quartzites. These bars are cut at regular intervals by transverse fractures. The play of strike-slip faulting and landslides that followed the first phases of erosion resulted in the isolation of relic slices whose alignment suggests membership of the same rock horizon. In the Figure $4 d$ example, 10-meter high bars underlie an allochthonous metric bloc probably emplaced by a landslide that preceded the isolation of the support. The "towers" appear as pseudo-prisms several meters high (Fig. 4e). These morphostructures probably represent ancient homogeneous rock horizons delimited by transverse and longitudinal fractures. The heterogeneity of the horizons makes the towers look more complex (Fig. 4f). 

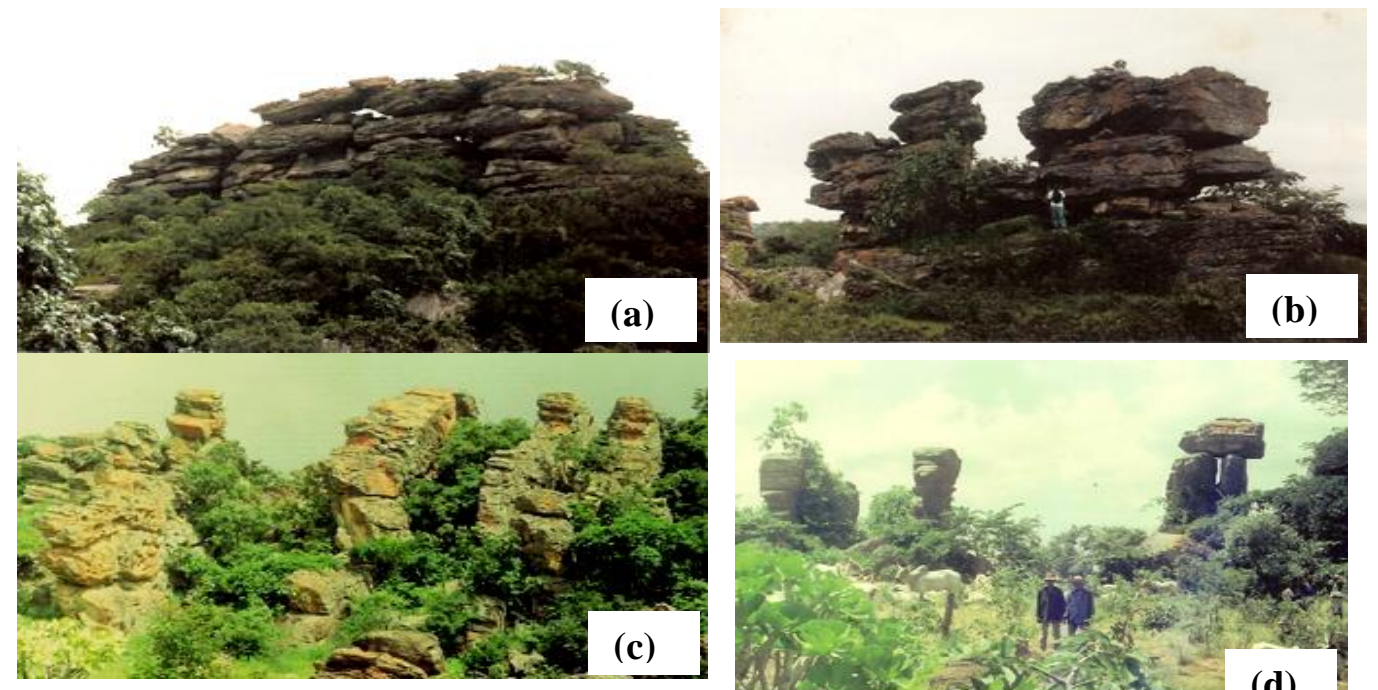

(c)
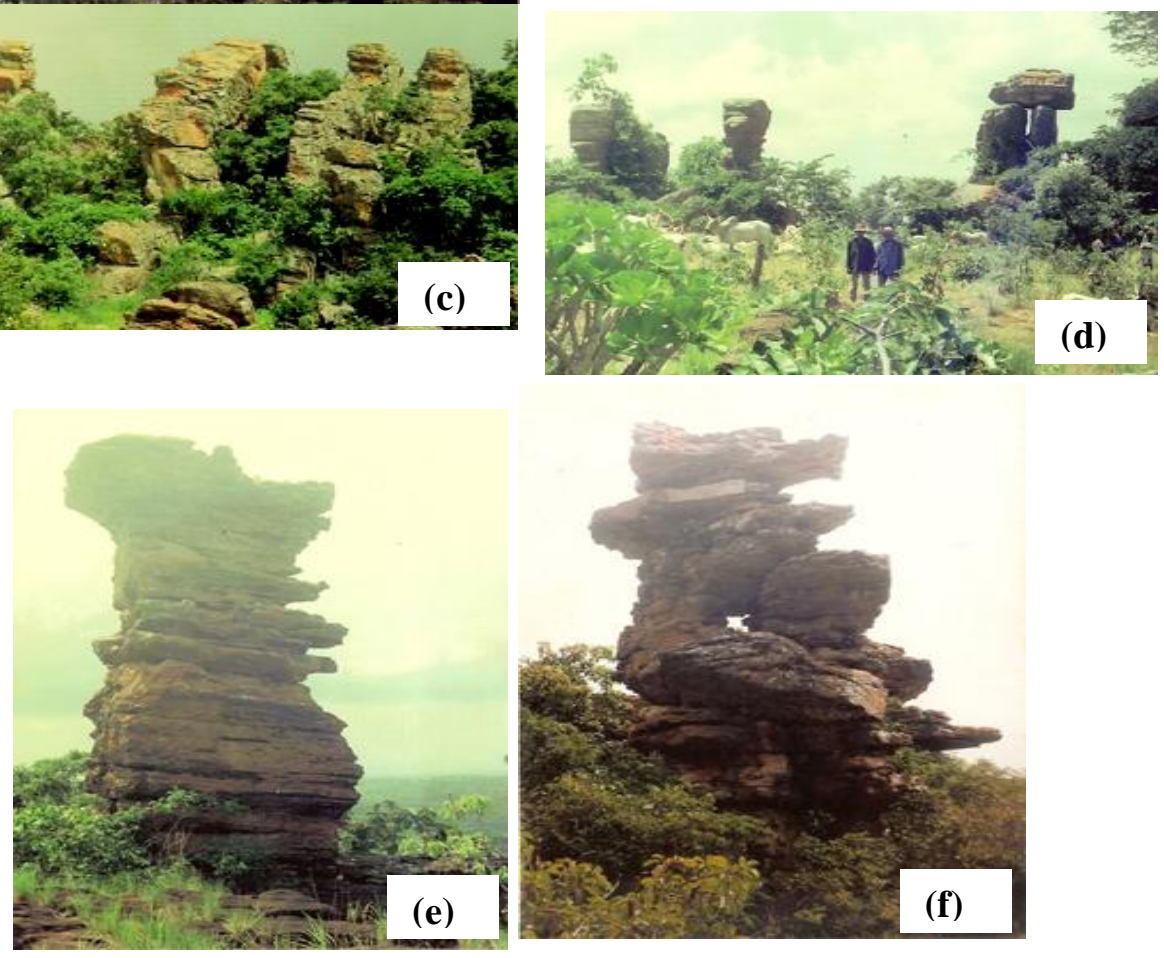

Fig. 4: Some ruiniform sculptures showing the fracturing/erosion factor, (a) "rock stacked", (b) "devil's vehicle, (c) "walls", (d) "raised bars" (e) and (f) "towers". 


\section{2 - Shapes Related to Folding/Erosion Factors}

These shapes are as impressive as those described above but they are less frequent because of the strong imprint of the late fracturing. Through these morphostructural types, relic frameworks sketch more or less demolished $P_{1}$ and $P_{2}$ folds marking the heritage of the redistribution of facies horizons by folding. The relic sculptures of the $P_{1}$ fold structure, refolded by $P_{2}$ folding, are called "reptile with a raised head" (Fig. 5a and b) or "devil's office" (Fig. 5c).

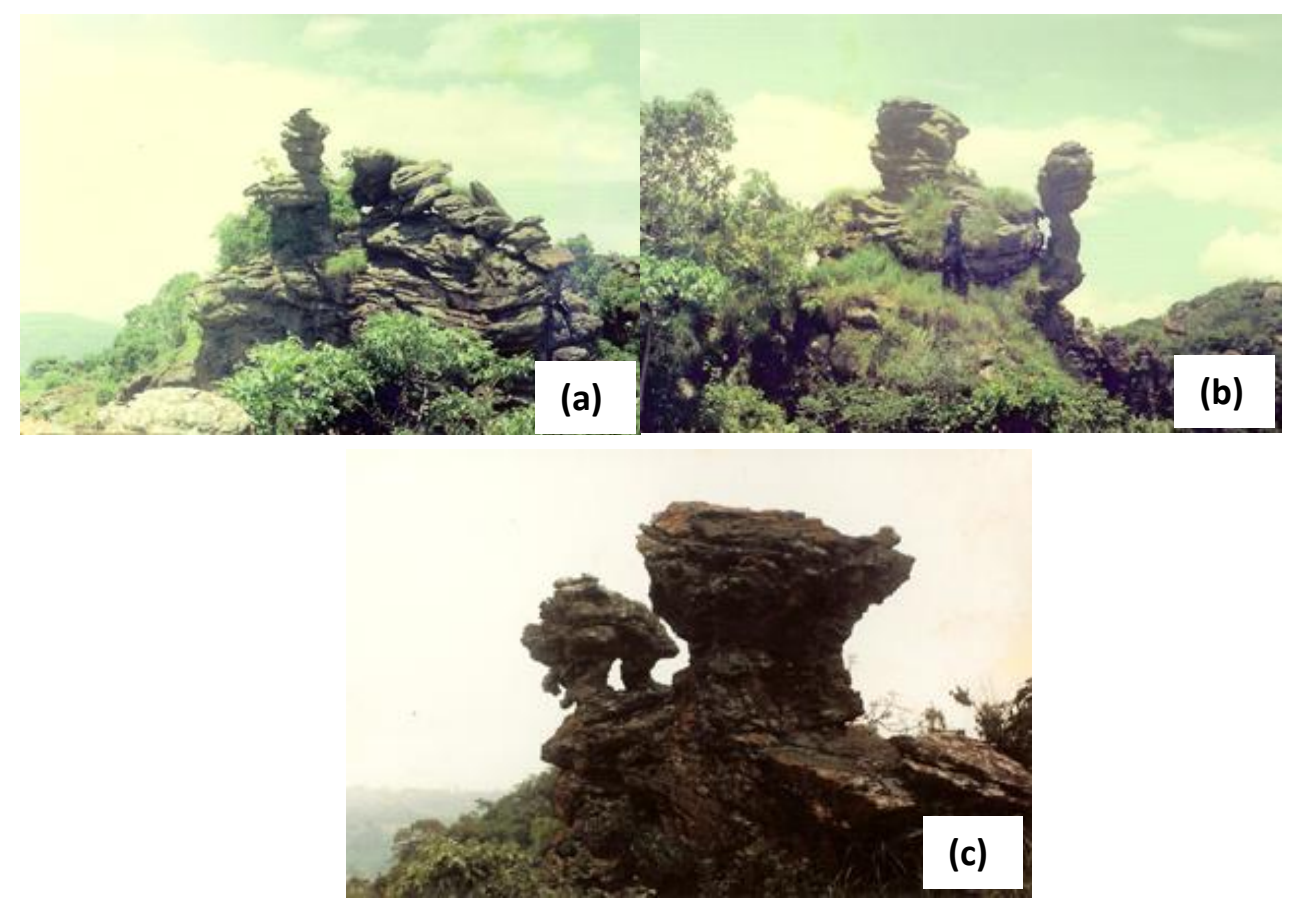

Fig. 5: Some ruiniform sculptures showing the folding/erosion factors (a) and (b) "reptile with raised head", (c) "devil's office".

\section{6 - Economic Potential}

In the Aledjo Mountains, there are human constructions in forms of rock barriers intended to block access to some areas. These historical constructions bear testimony to the protective strategic role of these mountains for the people who used to live there. But the present known economic value of these mountains resides in the use of the quartzites in residential construction, ballasting and ornamentation for which purposes the platy quartzites are exploited in artisanal quarries. On the contrary, the touristic potential of the Aledjo Mountains remains ignored. On tourist maps of Togo, the Aledjo area is symbolically designated as a "natural curiosity". In this regard, this curiosity is limited to the famous "Aledjo Fault" which is an adapted road in a narrow fault corridor while numerous other curiosities are ignored. This study is therefore intended as a contribution to the development of the tourist potential of these numerous natural monuments. Such a valorization of the geological patrimony agrees with the objectives of the "Association for the protection of the natural patrimony of the Aledjo Mountains" (APANAMA) which has as its ambition the inclusion of the Aledjo Mountains in the national or sub-regional touristic circuit.

\section{CONCLUSION}

The ruiniform landscapes of the Aledjo Mountains are carved in heterogeneous micaceousquartzite facies. The study of this erosional edifice reveals a conjunction of internal geodynamic factors, related to the Pan-African tectogenesis, and external geodynamic factors mainly due to a long process of post-Pan-African gullying.

These two groups of morphostructural factors confirm the importance of folding and fracturing in the genesis of the numerous variants of the ruiniform landscapes. The recognition of these facts might help to promote the hitherto unexploited touristic potential of the Aledjo Mountains, a factor in regional economic development.

\section{REFERENCES}

Affaton P., 1975. - Etude géologique et structurale du Nord-Ouest-Dahomey, du Nord-Togo et Sud-Est de la Haute-Volta. Thèse de 3è cycle, trav. Lab. Sci. Terre St. Jérôme, Marseille, Fr., ser. B, $217 p$. 
Affaton P., 1990. - Le bassin des Volta (Afrique de l'Ouest): une marge passive d'âge protérozoïque

supérieur, tectonisée au Panafricain (600 $\pm 50 \mathrm{Ma})$. Editions ORSTOM, Collections Etudes et Thèses, Paris, 500p.

Affaton P., Sougy J. and Trompette R., 1980. The Tectono-Stratigraphic Relationships between the Upper Precambrian and Lower Paleozoic Volta Basin and the Pan-African Dahomeyide Orogenic Belt (West Africa). Amer. J. Sci., vol. 280, pp. $224-248$.

Affaton P., Rahaman M. A., Trompette R. and Sougy J., 1991. The Dahomeyide Orogen: Tectonothermal Evolution and Relationships with the Volta Basin. In Dallmayer and Lécorché (Edit.): The West-African Orogen and Circum Atlantic Correlatives. Projet 233. 1CGP, IUGS, UNESCO, pp 107 - 122.

Agbossoumonde Y., Ménot R.-P., Paquette J.-L., Guillot S., Yessoufou S. and Perrache C., 2007. Petrological and Geochronological Constraints on the Origin of the Palimé-Amlamé Granitoids (South Togo, West Africa): A Segment of the West African Craton Paleoproterozoic Margin Reactivated during the Pan African Collision. Gondwana Research 12 (4) 476 - 488.

Caby R., 1989. Precambrian Terranes of Benin Nigeria and Northeast Brazil and the Late Protererozoic South Atlantic Fit. Geol. Soc. Am., special Paper 230, pp. $145-158$.

Caen-Vachette M., Pinto K. J. M., Roques M., 1979. Plutons éburnéens et métamorphisme dans le socle cristallin de la chaîne panafricaine au Togo et au Bénin. Rev. Géol. Dyn. Géogr. Phys. 21 (5), p. 351.

Carney J. N., Jordan C. J., Thomas C. W., Condon D. J., Kemp S. J. and Duodo J. A., 2010. Lithostratigraphiy, Sedimentation and Evolution of the Volta Basin in Ghana. Precambrian Research 183 (4), pp. 701-724.

Drouet J. J., 1986. Le cycle sédimentaire et les milieux de dépôt du précambrien supérieur infratillitique dans le bassin des Volta au Nord-Togo. Jour. Afric. Earth Sci., vol.5, n5, pp. 455-464.

Drouet J. J., Affaton P., Seddoh K. F., Godonou S. et Lawson L. T., 1984. Synthèse lithostratigraphique du précambrien supérieur infratillitique du bassin des Volta au Nord-Togo. In : Géol. Africaine -
African géology. Klernkx J. et Michot J. Edit., Tervuren, Belgique, pp. 217-225.

Kalsbeek F., Affaton P., Ekwueme B., Frei R. and Thrane K., 2012. Geochronology of Granitoid and Metasedimentary Rocks from Togo and Benin, West Africa: Comparisons with NE Brazil. Precambrian Research 196-197, pp. 218-233.

Noël Y., Pere N. B., Aregba A., Lawson T. L. and Godonou K. S., 1984. Notice explicative de la carte géologique au 1 / 200.000è, Feuille Kara. Dir. Gén. Min. Géol. / Bur. Nat. Rech. Min., Lomé, Ed. BRGM, Orléans, Fr. 36 p.

Simpara N., 1978. Etude géologique et structurale des unités externes de la chaîne panafricaine (600M.A.) des Dahomeyides dans la région de Bassar (Togo). Thèse 3è cycle univ. AixMarseille II Fr. 164p.

Simpara N., Sougy J. and Trompette R., 1985. Lithostratigraphie et structure du Buem, unité externe de la chaîne panafricaine des Dahomeyides de la région de Bassar (Togo). Jour. of Afr. Earth Sci., 3, n4, pp. $479-486$.

Sylvain J. P., Collar T., Aregba A. et Godonou S., 1986. Notice explicative de la carte géologique au 500000è du Togo. Mém. №6, Dir. Gén. Min. Géol./Bur. Nat. Rech. Min., Lomé, 120p.

Tairou M. S., 1995. Etude pétrographique et structurale d'un segment de la chaîne des Dahomeyides entre Sokodé et Bafilo (région centrale du Togo). Mém. de DEA, Univ. Nat. Cl. Abidjan, 80p.

Tairou M. S., 2006. La tectonique tangentielle panafricaine au Nord-Togo. Thèse Doctorat, Univ. Lomé, $\mathrm{n}^{\circ} 135$, 401p.

Tairou M. S., Affaton P., Sabi B. E. and Seddoh K. F., 2009. Tectono-Metamorphic Evolution of the Mo and Kara-Niamtougou Orthogneissic Suites, Northern Togo. Global Jour. of Geological Sciences, vol. $7 \mathrm{n}^{\circ} 2$, pp. $93-100$.

Tairou M. S., Affaton P., Gélard J.-P., Aite R. Sabi B. E., 2007. Panafrican Brittle Deformation and Paleostress Superposition in the Northern Togo (West Africa). C. R. Géosciences 339, pp. 849-857.

Trompette R., 1979. Les Dahomeyides au Bénin, Togo et Ghana: une chaîne de collision d'âge panafricain. Rev. Géol. Dyn. Géogr. Phys., 21, fasc. 5 , pp. $339-349$.

Woegan Y. A., 2007. - Diversité des formations végétales ligneuses du Parc National de FazaoMalfakassa et de la réserve de faune d'Alédjo (Togo). Thèse de Doctorat Univ. Lomé, 144p. 
